\title{
Antimicrobial susceptibility and virulence-associated genes in Campylobacter isolates from milk and wastewater in Hatay, Turkey
}

\author{
Mehmet Elmalı ${ }^{1}$ Hayriye Yeşim Can ${ }^{1 *}$ iD \\ ${ }^{1}$ Department of Food Hygiene and Technology, Faculty of Veterinary Medicine, Hatay Mustafa Kemal University, 31060 Alahan-Antakya,Hatay, \\ Turkey. E-mail: yesimcan@mku.edu.tr. "Corresponding author.
}

ABSTRACT: Campylobacter is one of the most common causes of bacterial foodborne diseases throughout the world. This study was conducted to determine the prevalence, antimicrobial resistance and virulence of Campylobacter isolates of raw cow's milk and cattle slaughterhouse wastewater samples in Hatay, Turkey. A total of 114 raw milk and 78 wastewater samples were analyzed for the identification of C. jejuni, C. coli, and C. lari by multiplex PCR. The overall prevalence of Campylobacter was found to be 7.2\%, of these isolates, $85.7 \%$ were identified as C. jejuni and $14.2 \%$ as C. coli, but C. lari was not detected in the study. The cdtA and cadF genes were present in $66.6 \%$ and $41.6 \%$ of $C$. jejuni isolates tested, respectively, but wlaN gene was not found in any of the isolates. Results of antimicrobial resistance analysis showed that $71.4 \%$ of the isolates were resistant to erythromycin, $64.2 \%$ to tetracycline, and $57.1 \%$ to ciprofloxacin. Overall, 8 of 14 Campylobacter isolates (57.1\%) showed a multidrug resistance.

Key words: antimicrobial resistance, Campylobacter, milk, wastewater.

Susceptibilidade antimicrobiana e genes associados à virulência em isolados de Campylobacter do leite e águas residuais em Hatay, Turquia

\begin{abstract}
RESUMO: Campylobacter é uma das causas mais comuns de doenças bacterianas de origem alimentar em todo o mundo. Este estudo foi conduzido para determinar a prevalência, a resistência antimicrobiana e a virulência de isolados de Campylobacter de leite de vaca cru e amostras de águas residuais de matadouros de gado em Hatay, na Turquia. Um total de 114 amostras de leite cru e 78 de águas residuais foram analisados para identificação de C. jejuni, C. coli e C. lari por PCR multiplex. A prevalência global de Campylobacter foi de 7,2\%, destes isolados, $85,7 \%$ foram identificados como C. jejuni e 14,2\% como C. coli, mas C. lari não foi detectado no estudo. Os genes cdtA e cadF estavam presentes em $66,6 \%$ e 41,6\% dos isolados de C. jejuni testados, respectivamente, mas o gene wlaN não foi encontrado em nenhum dos isolados. Os resultados da análise de resistencia antimicrobiana mostraram que 71,4\% dos isolados eram resistentes à eritromicina; $64,2 \%$ à tetraciclina e; 57,1\% à ciprofloxacina. Em geral, 8 dos 14 isolados de Campylobacter $(57,1 \%)$ apresentaram resistência a múltiplos fármacos. Palavras-chave: resistência antimicrobiana, Campylobacter, leite, águas residuais.
\end{abstract}

\section{INTRODUCTION}

Campylobacters are zoonotic, and main reservoirs of them are wild and domestic animals, especially intestinal tract of birds. Poultry meat, and its products are considered as the common source of Campylobacter infection in humans (PEZZOTTI et al., 2003; PÉREZ-BOTO et al., 2010; DUARTE et al., 2014; BOLTON, 2015; WIECZOREK \& OSEK, 2015; ZHONG et al., 2016), but also cattle may play an important role for human campylobacteriosis. There are cattle-related outbreaks both in the United States and Europe indicated that raw milk and dairy products are the second most frequently sources of infection (WHO, 2013). The most common symptom in campylobacteriosis in humans is acute gastroenteritis, but the infection is sometimes complicated with Guillian-Barré syndrome. Campylobacters are usually isolated from contaminated poultry meat, raw milk, and water (MOORE et al., 2001; DOMÍNGUEZ et al., 2002; PEZZOTTI et al., 2003; YANG et al., 2003; WHYTE et al., 2004; HUSSAIN et al.,2007; BARDOŇ et al., 2011).

Campylobacter jejuni and Campylobacter coli are most important species commonly associated with foodborne gastroenteritis. Campylobacter species are gram-negative, motile, termophilic and capnophilic bacteria that need microaerobic conditions for optimal growth. The minimal infective dose of $C$. jejuni is very low. It means that $C$. jejuni has a high virulence and very small numbers of bacteria cells could cause infection in humans (YANG et al., 2003; 
CHEN et al., 2010; BARDOŇ et al., 2011; GHARST et al., 2013). The virulence of Campylobacter species is associated with flagellar motility, adhesion, invasion and production of cytolethal distending toxins (ROZYNEK et al., 2005; MARTÍNEZ et al., 2006; WIECZOREK \& OSEK, 2008; RIPABELLI et al., 2010; GONZALEZ-HEIN et al., 2013; DI GIANNATALE et al., 2014; BOLTON, 2015). Fluoroquinolones and macrolides are frequently used in the treatment of campylobacteriosis, so that an increased level of resistance to these antimicrobials is observed in Campylobacter (PEZZOTTI et al., 2003; PÉREZ-BOTO et al., 2010; QIN et al., 2011; DI GIANNATALE et al., 2014; WIECZOREK et al., 2015; ZENDEHBAD et al., 2015)

Since the poultry and poultry meat are the most important sources of Campylobacter infections, many authors have studied the prevalence of Campylobacter on poultry in different countries (ZANETTI et al., 1996; DOMÍNGUEZ et al., 2002; PEZZOTTI et al., 2003; YANG et al., 2003; WHYTE et al., 2004; HUSSAIN et al., 2007; BARDOŇ et al., 2011; ZENDEHBAD et al., 2015; ZHONG et al., 2016). Also, recently there are a lots of reports regarding isolation of Campylobacter from raw milk and slaughter animals (GONZALEZ-HEIN et al., 2013; DI GIANNATALE et al., 2014; WYSOK et al., 2015a; WYSOK et al., 2015b; KALMUS et al., 2015; BERTASI et al., 2016; KASHOMA et al., 2016). But, searches in order to get more information about virulence mechanism and antimicrobial resistance profile of Campylobacter from these sources (raw milk, wastewater) are still limited. For this purpose, antimicrobial resistance and virulence genes of Campylobacter isolates recovered from raw milk and slaughterhouse wastewater samples were investigated in this study.

\section{MATERIALS AND METHODS}

A total of 114 raw cow's milk and 78 wastewater samples were collected from three different dairy farms and two cattle slaughterhouses in rural areas of Hatay province at a distance of 60 70 kilometers. All samples were aseptically taken at different times and were transported to the laboratory on the day of collection under cold chain. In the next step, $25 \mathrm{~mL}$ from each sample was placed into a sterile polyethylene bag containing $100 \mathrm{~mL}$ of Campylobacter Enrichment Broth (Base) (LAB135, Lab M, UK) supplemented with CAT (CefoperozoneAmphotericin B-Teicoplanin; FD145, Himedia, India) and incubated for 48 hours at $42^{\circ} \mathrm{C}$ under microaerobic conditions with using microaerophilic kits (Anaero Pack-MicroAero, MGC, Japan). Then, a loopful from all pre-enriched samples was streaked onto selective solid agar, Campylobacter Blood Free Medium Base Bolton (mCCDA, Biolife, Italy) supplemented with CCDA (Cefoperozone-Amphotericin B; SR0155, Oxoid). The plates were incubated at $42{ }^{\circ} \mathrm{C}$ for $24-48$ hours under microaerobic conditions (HUNT et al., 2001). Presumptive Campylobacter colonies were selected for further identification by PCR.

The isolates were identified to the genus/ species level by multiplex PCR. C. jejuni ATCC 29428 (Microbiologics, USA) and $C$. coli ATCC 43478 (Microbiologics, USA) were used as positive controls in molecular analysis. Four pairs of primers were used for amplifying the $16 S \mathrm{SRNA}$ gene specific for the genus Campylobacter (LINTON et al., 1996), the ask gene specific for $C$. coli (LINTON et al., 1997), the glyA gene specific for $C$. lari (WANG et al., 2002), and the cJ0414 gene specific for $C$. jejuni (WANG et al., 1992). The DNA extraction from the isolates was performed using a Bacterial DNA Extraction kit (Nucleic Acid Extraction Kit, GF-1, Vivantis, Malaysia), following the kit manufacturer's instructions. For DNA amplification, PCR protocol previously described by WANG et al. (2002) was used in the study.

In order to detect some virulence genes $(c a d F, c d t A, w l a N)$ in the isolates confirmed as C. jejuni, specific primers described by KONKEL et al. (1999), HICKEY et al. (2000), LINTON et al. (2000) were used. All primers used in the study are shown in table 1 . The PCR mixture and amplification of virulence genes were carried out according to DATTA et al. (2003), as previously described. Termalcycling conditions consisted of 30 cycles of $94{ }^{\circ} \mathrm{C}$ for $1 \mathrm{~min}$, annealing temperature for $1 \mathrm{~min}$, and $72{ }^{\circ} \mathrm{C}$ for $1 \mathrm{~min}$. The annealing temperature was set to $46{ }^{\circ} \mathrm{C}$ for $c a d F$, wlaN and to $49^{\circ} \mathrm{C}$ for $c d t A$.

All isolates were examined for antimicrobial resistance by determination of minimum inhibitory concentrations (MICs) on Mueller-Hinton agar (M1084, Himedia, India) by E-test (BAKER et al., 1991). The MICs were determined by using MIC test strips (Liofilchem, Italy) containing concentrations of the following antimicrobials: ciprofloxacin (0.002-32 mg/L), erythromycin (0.016$256 \mathrm{mg} / \mathrm{L})$, and tetracycline (0.016-256 mg/L). The MIC breakpoints were evaluated according to European Committee on Antimicrobial Susceptibility Testing (EUCAST) (EUCAST, 2014). The isolates resistant to three antimicrobials at the same time were considered as multidrug resistant. 
Table 1 - Primers for identification of Campylobacter isolates and detection of virulence genes.

\begin{tabular}{|c|c|c|c|}
\hline Genes & Sequences ( $5^{\prime}$ to $\left.3^{\prime}\right)$ & Product (bp) & Reference \\
\hline $\begin{array}{l}16 S \text { rRNA (Genus } \\
\text { Campylobacter) }\end{array}$ & GGATGACACTTTTCGGAGC & 816 & Linton et al. (1996) \\
\hline Ask (C. coli) & $\begin{array}{l}\text { GGTATGATTTCTACAAAGCGAG } \\
\text { ATAAAAGACTATCGTCGCGTG }\end{array}$ & 502 & Linton et al. (1997) \\
\hline $\operatorname{gly} A$ (C. lari) & $\begin{array}{l}\text { TAGAGAGATAGCAAAAGAGA } \\
\text { TACACATAATAATCCCACCC }\end{array}$ & 251 & Wang et al. (2002) \\
\hline cj0414 (C. jejuni) & $\begin{array}{l}\text { CAAATAAAGTTAGAGGTAGAATGT } \\
\text { CCATAAGCACTAGCTAGCTGAT }\end{array}$ & 161 & Wang et al. (1992) \\
\hline$w l a N$ & $\begin{array}{l}\text { TTAAGAGCAAGATATGAAGGTG } \\
\text { CCATTTGAATTGATATTTTTG }\end{array}$ & 672 & Linton et al. (2000) \\
\hline$c a d F$ & $\begin{array}{l}\text { TTGAAGGTAATTTAGATATG } \\
\text { CTAATACCTAAAGTTGAAAC }\end{array}$ & 400 & Konkel et al. (1999) \\
\hline$c d t A$ & $\begin{array}{l}\text { CCTTGTGATGCAAGCAATC } \\
\text { ACACTCCATTTGCTTTCTG }\end{array}$ & 370 & Hickey et al. (2000) \\
\hline
\end{tabular}

\section{RESULTS AND DISCUSSION}

In the current study, 114 raw milk and 78 cattle wastewater samples were analyzed for the presence of Campylobacter. A total of $14(7.2 \%)$ Campylobacter isolates were obtained from 192 samples. Of the raw milk samples, $6(5.2 \%)$ were found to be contaminated with Campylobacter jejuni. Overall, 6 (7.6\%) C. jejuni and 2 (2.5\%) C. coli strains were recovered from the wastewater samples. Results of the study demonstrated that wastewater samples were more frequently contaminated with Campylobacter than raw milk. The most prevalent species was $C$. jejuni with a rate of $85.7 \%(12 / 14)$. The remaining of isolates $(14.2 \%, 2 / 14)$ were confirmed as $C$. coli by PCR (Figure 1). In the study, C. lari was not detected.

Overall, 9 C. jejuni strains were found to have virulence genes. It was found that $C$. jejuni isolates harbored mainly $c d t A$ gene $(66.6 \%, 8 / 12)$ whereas the wlaN gene associated with GuillianBarré syndrome was not present in any of the isolates. Another virulence gene, $c a d F$ which encodes extramembrane proteins involved in adhesion and invasion, was detected in 5 of $12(41.6 \%)$ analyzed isolates.

Results of antimicrobial resistance analysis showed that 10 of 14 isolates $(71.4 \%)$ were resistant to erythromycin, $9(64.2 \%)$ to tetracycline and $8(57.1 \%)$ to ciprofloxacin. It was found that $8(57.1 \%)$ of the 14 Campylobacter isolates were resistant to all three antimicrobials at the same time. The most prevalent resistance profile observed in C. jejuni was erythromycin $(66.6 \%)$, followed by tetracycline $(58.3 \%)$ and ciprofloxacin (50\%). C. coli isolates were resistant to all three antimicrobials (Table 2).

When we examined some studies conducted in Turkey and in other countries, campylobacters were frequently isolated from poultry and poultry meat at high levels. Similary, C. jejuni was isolated as the most common species in many studies, followed by $C$. coli (ZANETTI et al., 1996; ELMALI \& YAMAN, 2004; WHYTE et al., 2004; HUSSAIN et al., 2007; BARDOŇ et al., 2011; WIECZOREK \& OSEK, 2015; ZENDEHBAD et al., 2015). C. coli is frequently isolated from pork (QIN et al., 2011; GHIMIRE et al., 2014; WYSOK et al., 2015a; WYSOK et al., 2015b). Although, the lower rates were detected in raw milk and dairy products (WHYTE et al., 2004; YAMAN \&ELMALI, 2004; HUSSAIN et al., 2007; BIANCHI et al., 2013; MODI et al., 2015; BERTASI et al., 2016; CHRISTIDIS et al., 2016) consistent with our results, YANG et al. (2003), EL-ZAMKAN\& ABDEL HAMEED (2016), DI GIANNATALE et al. (2014), KASHOMA et al. (2016) demonstrated a $27.3 \%, 20 \%, 17.2 \%, 13.4 \%$ prevalence of Campylobacter in milk samples, respectively. All this emphasizes the importance of raw milk and dairy products as a potential source of Campylobacter. But, Campylobacter was not detected in raw milk in studies from Estonia (KALMUS et al.,2015) and Finland (RUUSUNEN et al. (2013). Negative results may be due to sample 


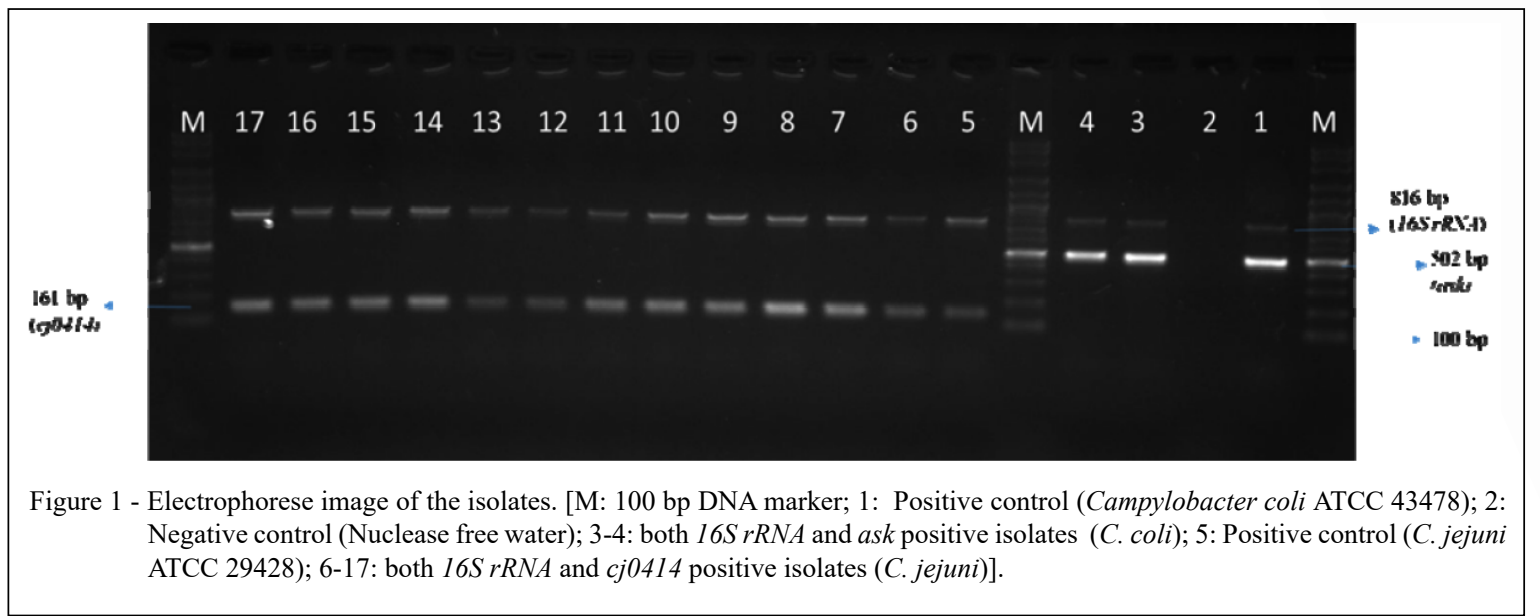

collection, transportation distance and conditions because Campylobacter is known to be very sensitive to environmental conditions.

Results obtained from different studies agree with the fact that $C$. jejuni is the most commonly detected Campylobacter species and high level contamination (over 50\%) with this pathogen is usually recorded in poultry (PEZZOTTI et al., 2003; ELMALI \& YAMAN, 2004; BARDOŇ et al., 2011; WYSOK et al. 2015b; ZENDEHBAD et al., 2015). This is because of Campylobacter species are thermophilic and adapt to poultry body temperature, poultry can easily become contaminated with this pathogen during slaughter and carcass dressing. However, previous studies reported the prevalence of Campylobacter in bovine carcass samples ranging from 9.5\% (KASHOMA et al., 2016), to $10.5 \%$ (WYSOK et al., 2015b) and

Table 2 - Antimicrobial susceptibility and virulence gene profiles of $C$. jejuni and $C$. Coli isolates from raw milk and cattle slaughterhouse wastewater samples.

\begin{tabular}{|c|c|c|c|c|c|c|c|}
\hline \multirow[t]{2}{*}{ Source of isolates } & \multirow[t]{2}{*}{ Code of isolates } & \multicolumn{3}{|c|}{------------Antimicrobals (Test range, $\mu \mathrm{g} / \mu \mathrm{L}$ )------------- } & \multicolumn{3}{|c|}{----------Virulence genes----. } \\
\hline & & $\mathrm{E}(0.016-256)$ & TE $(0.016-256)$ & CIP (0.002-32) & $c d t A$ & $c a d F$ & wlaN \\
\hline Raw milk & 2-C. jejuni & $>256(\mathrm{R})$ & $8(\mathrm{R})$ & $>32(\mathrm{R})$ & - & + & - \\
\hline Raw milk & 8-C. jejuni & $>256(\mathrm{R})$ & $12(\mathrm{R})$ & $>32(\mathrm{R})$ & + & + & - \\
\hline Raw milk & 9- C. jejuni & $>256(\mathrm{R})$ & $6(\mathrm{R})$ & $>32(\mathrm{R})$ & + & + & - \\
\hline Raw milk & 15-C. jejuni & $0.125(\mathrm{~S})$ & $0.023(\mathrm{~S})$ & $0.032(\mathrm{~S})$ & + & + & - \\
\hline Raw milk & 18-C. jejuni & $>256(\mathrm{R})$ & $12(\mathrm{R})$ & $>32(\mathrm{R})$ & - & - & - \\
\hline Raw milk & 21-C. jejuni & $0.19(\mathrm{~S})$ & $0.032(\mathrm{~S})$ & $0.125(\mathrm{~S})$ & + & + & - \\
\hline Wastewater & 4- C. coli & $>256(\mathrm{R})$ & $8(\mathrm{R})$ & $>32(\mathrm{R})$ & N/A & N/A & N/A \\
\hline Wastewater & 5- C. coli & $>256(\mathrm{R})$ & $6(\mathrm{R})$ & $>32(\mathrm{R})$ & N/A & N/A & N/A \\
\hline Wastewater & 14- C. jejuni & $>256(\mathrm{R})$ & $16(\mathrm{R})$ & $>32(\mathrm{R})$ & + & - & - \\
\hline Wastewater & 20-C. jejuni & $>256(\mathrm{R})$ & $96(\mathrm{R})$ & $0.25(\mathrm{~S})$ & + & - & - \\
\hline Wastewater & 21-C. jejuni & $>256(\mathrm{R})$ & $16(\mathrm{R})$ & $>32(\mathrm{R})$ & + & - & - \\
\hline Wastewater & 26-C. jejuni & $1.5(\mathrm{~S})$ & $0.125(\mathrm{~S})$ & $0.094(\mathrm{~S})$ & + & - & - \\
\hline Wastewater & 27-C. jejuni & $>256(\mathrm{R})$ & $2(\mathrm{~S})$ & $0.125(\mathrm{~S})$ & - & - & - \\
\hline Wastewater & 28-C. jejuni & $0.25(\mathrm{~S})$ & $0.047(\mathrm{~S})$ & $0.016(\mathrm{~S})$ & - & - & - \\
\hline
\end{tabular}

E: Erythromycin, TE: Tetracycline, CIP: Ciprofloxacin. S, Susceptible isolates; R, Resistant isolates. N/A, No data available. 
13.1\% (WYSOK et al., 2015a). Also, WESLEY et al. (2000) isolated Campylobacter from dairy cattle fecal samples at a level of $39.5 \%$, indicating that milk contamination may originate from fecal contamination during milking.

The prevalence of Campylobacter in wastewater samples in this study $(10.2 \%)$ is lower than that reported by YANG et al. (2003), but is higher than the results of MOORE et al. (2001) and YAMAN et al. (2005). Our results indicated that wastewaters from cattle salughterhouses may responsible for environmental contamination with campylobacters in Turkey. Wastewaters from cattle slaughterhouses generally originate from slaughter and rendering units and include blood, intestinal or rumen content. Therefore, contamination should be controlled by improving hygienic conditions at slaughterhouses within the framework of HACCP programs and slaughterhouses must have wastewater treatment plants.

Another part of the study was to evaluate the resistance of $C$. jejuni and $C$. coli isolates to some antimicrobials. Resistance to ciprofloxacin was frequently observed in $C$. coli isolated from wastewater $(100 \%)$, while lower rates were found in C. jejuni isolates (50\%), similar to PEZZOTTI et al. (2003). Resistance to erythromycin (71.4\%) was the most common resistance among the isolates different from the results of other authors (CHEN et al., 2010; BARDOŇ et al., 2011; DI GIANNATALE et al., 2014; DUARTE et al., 2014; WIECZOREK \& OSEK, 2015; ZENDEHBAD et al., 2015; ZHONG et al., 2016).

As has been observed before (PEZZOTTI et al., 2003; PÉREZ-BOTO et al., 2010; DI GIANNATALE et al., 2014; DUARTE et al., 2014; WIECZOREK \& OSEK, 2015), C. coli was more resistant to ciprofloxacin, erythromycin, and tetracycline than $C$. jejuni in our study. Similar to previous studies (CHEN et al., 2010; QIN et al., 2011; DUARTE et al., 2014; WIECZOREK et al., 2015; ZHONG et al., 2016), multidrug resistance was detected among $C$. coli and $C$. jejuni isolates. This result must be taken into account in treatment of campylobacteriosis. Also, the role of $C$. coli in human campylobacteriosis cannot be ignored due to its multidrug resistance profile.

With regard to the virulence properties of C. jejuni isolates, $75 \%$ of them carried virulenceassociate genes $(c d t A$ or $c a d F)$. Different from our study, WIECZOREK \& OSEK (2008) and ROZYNEK et al. (2005) reported cadF gene at most in their isolates. Similary, MARTINEZ et al.
(2006), RIPABELLI et al. (2010), GONZALEZHEIN et al. (2013), WYSOK et al. (2015a) detected high prevalence of the $c d t$ genes which are responsible for cytotoxin production. Finally, these results also indicated that $c d t$ genes are widespread among human and animal isolates in different countries.

\section{CONCLUSION}

C. jejuni was detected as the most prevalent species in the study, followed by C. coli. In addition, more than half of the isolates (57.1\%) showed multidrug resistance profiles. As a result, isolation of Campylobacter strains having virulence-associated genes and multidrug resistance from other sources (raw milk, wastewater) could be considered as an important risk both for human and environmental health.

\section{ACKNOWLEDGEMENTS}

The authors acknowledge the financial support of this research by the Department of Scientific Research Projects (Project code: 15170), Hatay Mustafa Kemal University, Turkey. A part of this study was presented at 4th International VETIstanbul Group Congress 11-13 May 2017, Almaty-Kazakhstan, and at International Congress of Health and Environment, 23-25 October 2017, Adana-Turkey.

\section{DECLARATION OF CONFLICT OF INTERESTS}

The authors declare no conflict of interest. The founding sponsors had no role in the design of the study; in the collection, analyses, or interpretation of data; in the writing of the manuscript, and in the decision to publish the results.

\section{AUTHORS' CONTRIBUTIONS}

The authors contributed equally to the manuscript.

\section{REFERENCES}

BAKER, C.N. et al. Comparison of the E Test to agar dilution, broth microdilution, and agar diffusion susceptibility testing techniques by using a special challenge set of bacteria.Journal of Clinical Microbiology, v.29, n.3, p.533-538, 1991. Available from: <https://www.ncbi.nlm.nih. gov/pmc/articles/PMC269813/>. Accessed: Jan. 30, 2019.

BARDOŇ, J. et al. Prevalence of thermotolerant Campylobacter spp. in broilers at retail in the Czech Republic and their antibiotic resistance. Food Control, v.22, n.2, p.328-332, 2011. Available from: $<$ https:// www.sciencedirect.com/science/article/pii/S0956713510002537>. Accessed: Feb. 05, 2018. doi: 10.1016/j.foodcont.2010.08.001.

BERTASI, B. et al. Seasonal variability of thermophilic Campylobacterspp. in raw milk sold by automatic vending 
machines in Lombardy Region. Italian Journal of Food Safety, v.5, n.3, p.131-133, 2016.Available from: <https://www.ncbi.nlm. nih.gov/pmc/articles/PMC5090118/>. Accessed: Jan. 30, 2019. doi: $10.4081 /$ ijfs.2016.5848.

BIANCHI, D.M. et al. Monitoring of foodborne pathogenic bacteria in vending machine raw milk in Piedmont, Italy. Food Control, v.32, n.2, p.435-439, 2013. Available from: <https:// www.sciencedirect.com/science/article/pii/S0956713513000194>. Accessed: Jan. 30, 2019. doi: 10.1016/j.foodcont.2013.01.004.

BOLTON, D.J. Campylobacter virulence and survival factors. Food Microbiology, v.48, p.99-108, 2015. Available from: $<\mathrm{https}: / /$ www.sciencedirect.com/science/article/pii/S0740002014003037>. Accessed: Feb. 05, 2018. doi: 10.1016/j.fm.2014.11.017.

CHEN, X. et al. Prevalence and antimicrobial resistance of Campylobacter isolates in broilers from China. Veterinary Microbiology, v.144, n.1-2, p.133-139, 2010. Available from: $<$ https:// www.sciencedirect.com/science/article/pii/S0378113510000076> Accessed: Feb. 05, 2018. doi: 10.1016/j.vetmic.2009.12.035.

CHRISTIDIS, T. et al. Campylobacter spp. prevalence and levels in raw milk: A systematic review and meta-analysis. Journal of Food Protection, v.79, n.10, p.1775-1783, 2016. Available from: $<$ http://www.jfoodprotection.org/doi/abs/10.4315/0362-028X. JFP-15-480 code=FOPR-site $>$. Accessed: Sep. 03, 2018. doi: 10.4315/0362-028X.JFP-15-480.

DATTA, S. et al.Prevalence of 11 pathogenic genes of Campylobacter jejuni by PCR in strains isolated from humans, poultry meat and broiler and bovine faeces. Journal of Medical Microbiology, v.52, p.345-348, 2003. Available from: <http:// jmm.microbiologyresearch.org/content/journal/jmm/10.1099/ jmm.0.05056-0>. Accessed: Feb. 27, 2018. doi: 10.1099/ jmm.0.05056-0.

DI GIANNATALE, E. et al. Characterization of antimicrobial resistance patterns and detection of virulence genes in Campylobacterisolates in Italy. Sensors, v.14, n.2, p.33083322, 2014. Available from: <https://www.mdpi.com/14248220/14/2/3308/htm>. Accessed: Jan. 30, 2019. doi:10.3390/ s140203308.

DOMÍNGUEZ, C. et al. Prevalence of Salmonella and Campylobacter in retail chicken meat in Spain. International Journal of Food Microbiology, v.72, n.1-2, p.165-168, 2002. Available from: <https://www.sciencedirect.com/science/article/ pii/S0168160501006389>. Accessed: Feb. 05, 2018. doi: 10.1016/ S0168-1605(01)00638-9.

DUARTE, A. et al.Human, food and animal Campylobacter spp. isolated in Portugal: High genetic diversity and antibiotic resistance rates. International Journal of Antimicrobial Agents, v.44, n.4, p.306-313, 2014. Available from: <http://www.ijaaonline.com/ article/S0924-8579(14)00207-6/fulltext>. Accessed: Feb. 13, 2018. doi: 10.1016/j.ijantimicag.2014.06.012.

ELMALI, M.; YAMAN, H. Thermophilic Campylobacter spp. on frozen poultry carcasses.Journal of the Faculty of Veterinary Medicine, Kafkas University, v.10, n.1, p.27-30, 2004. Available from: <http://vetdergikafkas.org $>$. Accessed: Feb. 06, 2018

EL-ZAMKAN, M.A.; ABDEL HAMEED, K.G. Prevalence of Campylobacter jejuni and Campylobacter coli in raw milk and some dairy products. Veterinary World, v.9, n.10, p.1147-1151, 2016. Available from: <https://www.ncbi.nlm.nih.gov/pmc/ articles/PMC5104726/>. Accessed: Sep. 03, 2018. doi: 10.14202/ vetworld.2016.1147-1151.

EUCAST. European Committee on Antimicrobial Susceptibility Testing. Breakpoints tables for interpretation of MICs and zone diameters. Version 4.0, 2014. Available from: <http://www.eucast. org >. Accessed: Feb. 13, 2018.

GHARST, G. et al. Review of current methodologies to isolate and identify Campylobacter spp. from foods. Journal of Microbiological Methods, v.95, n.1, p.84-92, 2013. Available from: $\quad<$ https://www.sciencedirect.com/science/article/pii/ S0167701213002315>. Accessed: Feb. 06, 2018. doi: 10.1016/j. mimet.2013.07.014

GHIMIRE, L. et al. Prevalence, antibiogram and risk factors of thermophilic campylobacter spp. in dressed porcine carcass of Chitwan, Nepal.BMC Microbiology, v.14, n.85, p.1-7, 2014. Available from: $<$ https://bmcmicrobiol.biomedcentral.com/ articles/10.1186/1471-2180-14-85>. Accessed: May. 10, 2018. doi: $10.1186 / 1471-2180-14-85$

GONZALEZ-HEIN, G. et al. Prevalence of virulence genes in strains of Campylobacter jejuni isolated from human, bovine and broiler. Brazilian Journal of Microbiology, v.44, n.4, p.1223-1229, 2013. Available from: <http://www.scielo.br/ scielo.php?pid $=\mathrm{S} 1517-83822013000400028 \&$ script $=\mathrm{sci}$ arttext>. Accessed: Jan. 30, 2019. doi: 10.1590/S151783822013000400028

HICKEY, T.E. et al. Campylobacter jejunicytolethal distending toxin mediates release of interleukin-8 from intestinal epithelial cells. Infection and Immunity, v.68, n.12, p. 6535-6541, 2000. Available from: <http://iai.asm.org/content/68/12/6535. short $>$. Accessed: Feb. 26, 2018. doi: 10.1128/IAI.68.12.65356541.2000 .

HUNT, J.M. et al. Bacteriological Analytical Manual (BAM): Campylobacter. Chapter 7, 2001. Available from: <https:// www.fda.gov/Food/FoodScienceResearch/LaboratoryMethods/ ucm072616.htm>. Accessed: Feb. 06, 2018.

HUSSAIN, I. et al. Prevalence of Campylobacter species in meat, milk and other food commodities in Pakistan.Food Microbiology, v.24, n.3, p.219-222, 2007. Available from: <https://www. sciencedirect.com/science/article/pii/S0740002006001109>. Accessed: Feb. 06, 2018. doi: 10.1016/j.fm.2006.06.001.

KALMUS, P. et al. Quality of raw milk intended for direct consumption in Estonia.Food Control, v.51, p.135-139, 2015. Available from: <https://www.sciencedirect.com/science/article/ pii/S0956713514006525>. Accessed: Jan. 30, 2019. doi: 10.1016/j. foodcont.2014.11.018.

KASHOMA, I.P. et al. Prevalence and antimicrobial resistance of Campylobacter isolated from dressed beef carcasses and raw milk in Tanzania. Microbial Drug Resistance, v.22, n.1, p.4052, 2016. Available from: <https:/www.liebertpub.com/doi/ abs/10.1089/mdr.2015.0079>. Accessed: Jan. 30, 2019. doi: 10.1089/mdr.2015.0079.

KONKEL, M.E. et al. Identification of the enteropathogens Campylobacter jejuni and Campylobacter coli based on the cadF virulence gene and its product. Journal of Clinical Microbiology, 
v.37, n.3, p.510-517, 1999. Available from: <http://jcm.asm.org/ content/37/3/510.short>. Accessed: Feb. 27, 2018

LINTON, D. et al. Rapid identification by PCR of the genus Campylobacter and of five Campylobacter species enteropathogenic 5etüs5n and animals. Research in Microbiology, v.147, n.9, p.707-718, 1996. Available from: <https://www.sciencedirect. com/science/article/pii/S0923250897851182>. Accessed: Feb. 26, 2018. doi: 10.1016/S0923-2508(97)85118-2.

LINTON, D. et al.PCR detection, identification to species level, and fingerprinting of Campylobacter jejuni and Campylobacter coli direct from diarrheic samples. Journal of Clinical Microbiology, v.35, n.10, p.2568-2572, 1997. Available from: <http://jcm.asm. org/content/35/10/2568.short>. Accessed: Feb. 26, 2018.

LINTON, D. et al. Phase variation of a $\beta-1,3$ galactosyltransferase involved in generation of the ganglioside GM1-like lipooligosaccharide of Campylobacterjejuni.Molecular Microbiology, v.37, n.3, p.501-514, 2000.Available from: <http://onlinelibrary. wiley.com/doi/10.1046/j.1365-2958.2000.02020.x/full> Accessed: Feb. 26, 2018. doi: 10.1046/j.1365-2958.2000.02020.x.

MARTÍNEZ, I. et al. Detection of $c d t A, c d t B$, and $c d t C$ genes in Campylobacter jejuni by multiplex PCR. International Journal of Medical Microbiology, v.296, n.1, p.45-48, 2006 Available from: <https://www.sciencedirect.com/science/ article/pii/S1438422105001414>. Accessed: Feb. 06, 2018. doi: 10.1016/j.ijmm.2005.08.003.

MODI, S. et al. Prevalence of Campylobacter species in milk and milk products, their virulence gene profile and antibiogram. Veterinary World, v.8, n.1, p.1-8, 2015. Available from: <https:/ www.ncbi.nlm.nih.gov/pmc/articles/PMC4777796/>. Accessed: Sep. 03, 2018. doi: 10.14202/vetworld.2015.1-8.

MOORE, J. et al. Molecular detection of Campylobacter spp. in drinking, recreational and environmental water supplies. International Journal of Hygiene and Environmental Health, v.204, n.2-3, p.185-189, 2001. Available from: <https://www. sciencedirect.com/science/article/pii/S1438463904700929>. Accessed: Feb. 07, 2018. doi: 10.1078/1438-4639-00096.

PÉREZ-BOTO, D. et al. Study of the molecular mechanisms involved in high-level macrolide resistance of Spanish Campylobacter jejuni and Campylobacter coli strains. Journal of Antimicrobial Chemotherapy, v.65, p.2083-2088, 2010. Available from: < https://academic.oup.com/jac/article/65/10/2083/704378>. Accessed: Feb. 05, 2018. doi: 10.1093/jac/dkq268.

PEZZOTTI, G. et al. Occurrence and resistance to antibiotics of Campylobacter jejuni and Campylobacter coli in animals and meat in northeastern Italy. International Journal of Food Microbiology, v.82, n.3, p.281-287, 2003. Available from: <https:// www.sciencedirect.com/science/article/pii/S0168160502003148>. Accessed: Feb. 06, 2018. doi: 10.1016/S0168-1605(02)00314-8.

QIN, S.S. et al. Antimicrobial resistance in Campylobacter coli isolated from pigs in two provinces of China. International Journal of Food Microbiology, v.146, n.1, p.94-98, 2011. Available from: <https://www.sciencedirect.com/science/article/ pii/S0168160511000420>. Accessed: Feb. 06, 2018. doi: 10.1016/j. ijfoodmicro.2011.01.035.

RIPABELLI, G. et al. Prevalence of virulence-associated genes and cytolethal distending toxin production in Campylobacter spp. isolated in Italy. Comparative Immunology, Microbiology and Infectious Diseases, v.33, n.4, p.355-364, 2010. Available from: $<$ https://www.sciencedirect.com/science/ article/pii/S014795710800091X>. Accessed: Feb. 06, 2018. doi: 10.1016/j.cimid.2008.12.001.

ROZYNEK, E. et al. Prevalence of potential virulence markers in Polish Campylobacter jejuni and Campylobacter coli isolates obtained from hospitalized children and from chicken carcasses. Journal of Medical Microbiology, v.54, p.615-619, 2005. Available from: <http://jmm.microbiologyresearch.org/content/ journal/jmm/10.1099/jmm.0.45988-0>. Accessed: Feb. 06, 2018. doi: $10.1099 /$ jmm.0.45988-0.

RUUSUNEN, M. et al. Pathogenic bacteria in Finnish bulk tank milk.Foodborne Pathogens and Disease, v.10, n.2, p.99106, 2013. Available from: <https://www.liebertpub.com/doi/ abs/10.1089/fpd.2012.1284>. Accessed: Jan. 30, 2019. doi: $10.1089 /$ fpd.2012.1284

WANG, R.F. et al.A rapid PCR methodfor directdetection of lownumbers of Campylobacter jejuni. Journal of Rapid Methods and Automation in Microbiology, v.1, n.2, p.101108, 1992. Available from: <http://onlinelibrary.wiley.com/ doi/10.1111/j.1745-4581.1992.tb00074.x/full>. Accessed: Feb. 26, 2018. doi: 10.1111/j.1745-4581.1992.tb00074.x.

WANG, G. et al.Colony multiplex PCR assay for identification and differentiation of Campylobacter jejuni, C. coli, C. lari, C. upsaliensis, and C. fetus subsp. fetus. Journal of Clinical Microbiology, v.40, n.12, p.4744-4747, 2002. Available from: $<$ http://jcm.asm.org/content/40/12/4744.short $>$. Accessed: Feb. 26, 2018. doi: 10.1128/JCM.40.12.4744-4747.2002.

WESLEY, I.V. et al. Fecal shedding of Campylobacter and Arcobacter spp. in dairy cattle. Applied and Environmental Microbiology, v.66, n.5, p.1994-2000, 2000. Available from: $<$ https://aem.asm.org/content/66/5/1994.short>. Accessed: Jan. 30, 2019. doi: 10.1128/AEM.66.5.1994-2000.2000.

WHO. The global view of campylobacteriosis. Report of an expert consultation.World Health Organization ed., Geneva, Switzerland, 2013. Available from: <www.who.int/iris/ bitstream/10665/80751/1/9789241564601_eng.pdf $>$. Accessed: Jan. 30, 2019.

WHYTE, P. et al. Occurrence of Campylobacter in retail foods in Ireland. International Journal of Food Microbiology, v.95, n.2, p.111-118, 2004. Available from: <https:/www.sciencedirect. com/science/article/pii/S0168160504001060>. Accessed: Feb. 06, 2018. doi: 10.1016/j.ijfoodmicro.2003.10.018.

WIECZOREK, K.; OSEK, J. Identification of virulence genes in Campylobacter jejuni and C. coli isolates by PCR. Bulletin of the Veterinary Institute in Pulawy, v.52, p.211-216, 2008.

WIECZOREK, K.; OSEK, J. A five-year study on prevalence and antimicrobial resistance of Campylobacter from poultry carcasses in Poland. Food Microbiology, v.49, p.161-165, 2015. Available from: $<$ https://www.sciencedirect.com/science/ article/pii/S0740002015000301>. Accessed: Feb. 05, 2018. doi: 10.1016/j.fm.2015.02.006.

WIECZOREK, K. et al. Comparative analysis of antimicrobial resistance and genetic diversity of Campylobacter from broilers slaughtered in Poland. International Journal of Food 
Microbiology, v.210, p.24-32, 2015. Available from: <https://www. sciencedirect.com/science/article/pii/S0168160515300325>. Accessed: Feb. 06, 2018. doi: 10.1016/j.ijfoodmicro.2015.06.006.

WYSOK, B. et al. Determination of the cytotoxic activity of Campylobacter strains isolated from bovine and swine carcasses in north-eastern Poland. Polish Journal of Veterinary Sciences, v. 18 , n.3, p.579-586, 2015a. Available from: <https://content.sciendo. com/view/journals/pjvs/18/3/article-p579.xml>. Accessed: Jan. 30, 2019. doi: 10.1515/pjvs-2015-0075.

WYSOK, B. et al. Prevalence and antimicrobial resistance of Campylobacter spp. strains isolated from slaughter animals and human. Medycyna Weterynaryjna, vol.71, n.12 p.801-806, 2015b. Available from: <https://www.cabdirect.org/cabdirect/ abstract/20153437851>. Accessed: Jan. 30, 2019.

YAMAN, H.; ELMALI, M. The occurence of thermophilic Campylobacter (C. jejuni) in raw milk. Journal of the Faculty of Veterinary Medicine, Kafkas University, v.10, n.1, p.37-40, 2004 Available from: $<$ http://vetdergikafkas.org $>$. Accessed: Feb. 06, 2018.

YAMAN, H. et al. Presence of Campylobacter (C. jejuni) in recreational, lake and stream water and fresh fish in Turkey. Archiv für Lebensmittelhygiene, v.56, n.4, p.83-86, 2005. Available from: $<$ https://www.cabdirect.org/cabdirect/abstract/20053180755>. Accessed: Feb. 06, 2018.
YANG, C. et al. Application of real-time PCR for quantitative detection of Campylobacter jejuni in poultry, milk and environmental water. FEMS Immunology \& Medical Microbiology, v.38, n.3, p.265-271, 2003. Available from: <https://academic.oup.com/femspd/ article/38/3/265/583068>. Accessed: Feb. 06, 2018. doi: 10.1016/S0928-8244(03)00168-8.

ZANETTI, F. et al. Prevalence of thermophilic Campylobacter and Arcobacter butzleri in food of animal origin. International Journal of Food Microbiology, v.33, n.2-3, p.315-321, 1996. Available from: <https://www.sciencedirect.com/science/ article/pii/016816059601166X $>$. Accessed: Feb. 06, 2018. doi: 10.1016/0168-1605(96)01166-X.

ZENDEHBAD, B. et al. Prevalence, seasonality and antibiotic susceptibility of Campylobacter spp. isolates of retail broiler meat in Iran. Food Control, v.53, p.41-45, 2015. Available from: $<$ https:// www.sciencedirect.com/science/article/pii/S0956713515000213>. Accessed: Feb. 06, 2018. doi: 10.1016/j.foodcont.2015.01.008.

ZHONG, $X$. et al. Prevalence, genetic diversity and antimicrobial susceptibility of Campylobacter jejuni isolated from retail food in China. Food Control, v.62, p.10-15, 2016. Available from: <https://www.sciencedirect.com/science/ article/pii/S0956713515302115>. Accessed: Feb. 06, 2018. doi: 10.1016/j.foodcont.2015.09.032. 